\title{
Correction to: Exploring students' science motivation across grade levels and the role of inductive reasoning in science motivation
}

\section{De Van Vo ${ }^{1,2}$ (D) Benő Csapó ${ }^{3,4}$ (D)}

Published online: 25 September 2021

(c) Instituto Universitário de Ciências Psicológicas, Sociais e da Vida 2021

\section{Correction to: European Journal of Psychology of Education https://doi.org/10.1007/s10212-021-00568-8}

The original version of the article unfortunately contained an error.

A data was inadvertently added in the first author's affiliation. The correct author affiliation is shown below.

The original article has been corrected.

Publisher's note Springer Nature remains neutral with regard to jurisdictional claims in published maps and institutional affiliations.

The original article can be found online at https://doi.org/10.1007/s10212-021-00568-8.

De Van Vo

vo.de.van@edu.u-szeged.hu

Benő Csapó

csapo@edpsy.u-szeged.hu

1 Doctoral School of Education, University of Szeged, 32-34. Petőfi S. sgt., Szeged H-6722, Hungary

2 An Giang University - VNUHCM, 18 Ung Van Khiem, Long Xuyen, An Giang, Vietnam

3 Institute of Education, University of Szeged, 32-34. Petőfi S. sgt., Szeged H-6722, Hungary

4 MTA-SZTE Research Group on the Development of Competencies, Szeged, Hungary 